\title{
COMPUTED TOMOGRAPHY OF THE SPINE AND SPINAL CORD; LIMITATIONS AND APPLICATIONS
}

\author{
By H. J. HACHEN \\ Spinal Injuries Centre, Geneva University Hospital, Switzerland
}

\begin{abstract}
The author presents a comprehensive review of the literature on spinal computerized tomography in the evaluation of spinal fractures and fracture-dislocations, degenerative processes with bony encroachment into the spinal canal, disc protrusion, cystic degeneration of the cord, communicating hydro-syringomyelia, intra- and extramedullary neoplasms and congenital malformations. Critical analysis of all published data and additional personal experience gained over the past three years make it possible to better define the clinical applications and practical limitations of spinal CT scans.
\end{abstract}

Key words: Computed spinal tomography; Spinal cord trauma; Syringomyelia, Metrizamide myelography.

In the recent past there have been some major advances in the neuroradiological exploration of the spinal canal and its contents. The introduction of metrizamide (Amipaque ${ }^{\circledR}$ ), a water-soluble, isotonic contrast agent, has significantly contributed to improved myelography with lesser side effects. Its use in combination with high-resolution computed tomography has proved to be of immense value in the non-invasive evaluation of a wide range of spinal and medullary lesions (Jacobson et al., 1975; Di Chiro and Schellinger, 1976; Skalpe and Sortland, I978).

In the following review we report on the results obtained with spinal CT scans in our spinal unit at the Geneva University Hospital.

\section{Neuroradiological Investigations}

Among the wide range of techniques that are currently available none is fully exhaustive. Each single method has its advantages and shortcomings, depending on the nature of the pathological state that requires neuroradiological investigation. The various methods are therefore mostly complementary. Good plain films should always be available before one considers any more specialised procedures. In fact standard X-rays often already provide valuable information with regard to the location and probable longitudinal extension of a pathological process.

\section{Gas myelography}

Since the introduction of metrizamide-enhanced CT the indications for gas myelography have become quite rare. The method is still used for the study of hydromyelia and intraspinal collapsing arachnoid cysts. Haughton's (1978) technique $\left(5^{\circ}\right.$ and $25^{\circ}$ head-down tilt) which causes only minimal intracranial leakage of oxygen is generally preferred to Westberg's (I966) method (head-up $v s$. head-down). A collapsing cord is compatible with the diagnosis of cystic spinal cord disease. 


\section{Myeloscintigraphy}

The lumbar intrathecal introduction of ${ }^{99} \mathrm{Tc}$-marked serum albumin has been proposed for the study of CSF-kinetics. In the thoracic and upper lumbar levels the method has been successfully used to demonstrate myeloradicular compression. At the cervical and lower lumbar levels it is less reliable. Lateral herniated discs may easily be overlooked.

\section{Computed tomography (CT)}

Opening an entirely new dimension in the assessment of the spine and spinal cord, CT scanning yields particularly interesting results in the diagnostic evaluation of fracture-dislocations, congenital vertebral malformations and degenerative spinal lesions causing bony encroachment into the spinal canal. CT scanning is a relatively quick examination which we always perform in the supine position, thus avoiding any unnecessary and potentially dangerous manipulations in patients with acute spinal trauma. Soft tissue abnormalities within the canal are more difficult to visualise. Two technical improvements have therefore been proposed:

Intravenous injection of contrast material in order to enhance the density of the epidural space;

Intrathecal injection of metrizamide in order to better delineate the subarachnoid space (Coin et al., 1978).

Metrizamide-CT is clearly superior to conventional myelography in patients with traumatic, stenotic and dysraphic conditions.

\section{The normal spine and spinal cord}

Computerised axial tomography renders a highly accurate image of the vertebral anatomy. It allows precise visualisation of any structural changes of the vertebral bodies, laminae, pedicles, facet joints and transverse processes (Sheldon et al., 1977). Normal reference values have been obtained both for the spinal canal and the spinal cord. These investigations have shown that between $\mathrm{CI}_{\mathrm{I}}$ and L5 the canal changes from an oval into a triangular shape and that its sagittal (antero-posterior) diameter always remains above Io mm (Lohkamp et al., I978).

The structures within the spinal canal normally have a homogeneous appearance. The cord and cauda equina are indistinguishable from the subarachnoid space (Scotti et al., 1977). Absorption values within the canal vary from -20 to + 20 EMI units. The normal cord appears as a central density which is surrounded by a low density halo of cerebrospinal fluid (Oberson et al., I978). In our experience the thoracic cord and the cauda equina are technically more difficult to delineate than the cervical cord.

\section{Traumatic lesions \\ Pathological conditions of the spine and spinal cord}

CT scans provide detailed information regarding the degree of spinal cord compression (Lin et al., I977). The fracture lines are readily visualised (Fig. I). Small bony fragments which are frequently missed on plain radiographs (Fig. 2) can easily be demonstrated with CT within the canal (Colley \& Dunsker, I978). We consider the method of greater value than conventional myelography in determining the advisability of emergency neurosurgical treatment (Fig. 3). 


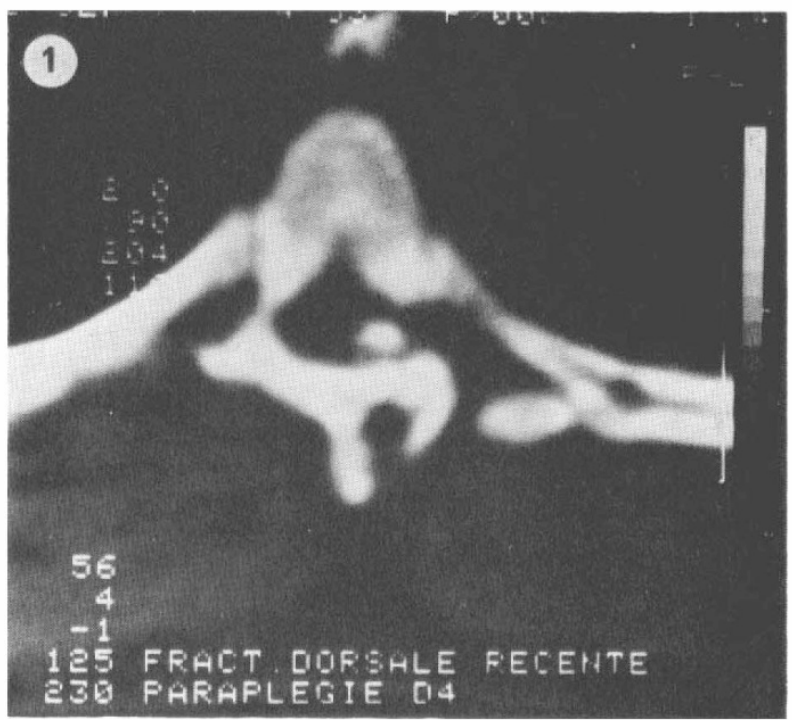

FIG. I

Case 450903; male; age 35; complete paraplegia $\mathrm{Th}_{4}$ - $\mathrm{Th} 5$; slight anterior compression fracture of Th4 with concomitant fracture of the left pedicle and upper facet. Lateral myeloradicular compression by small bony fragment protruding into the canal.
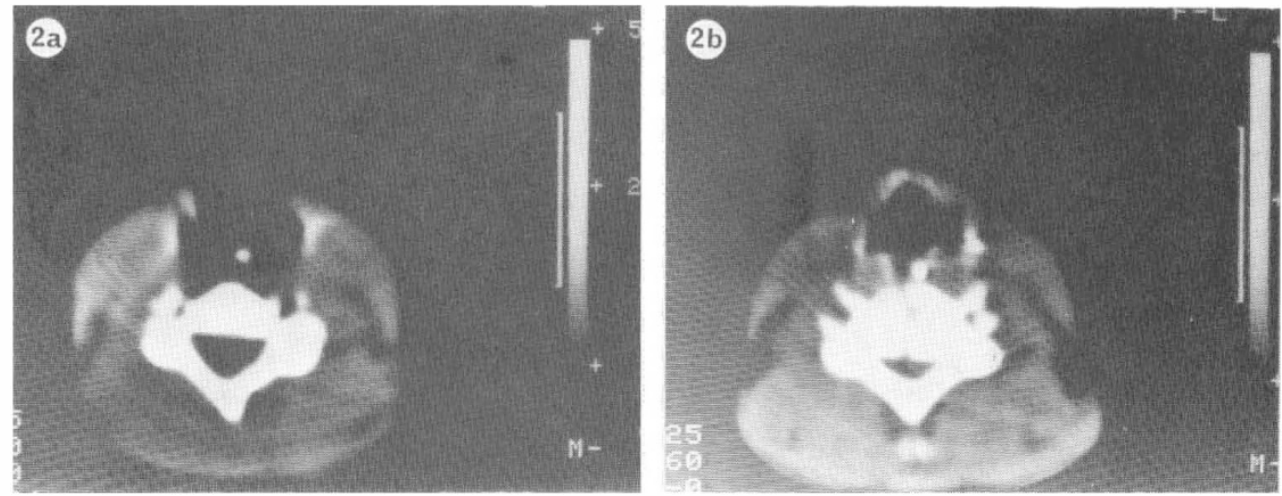

FIG. 2

Case 56042I; female; age 23; complete tetraplegia $\mathrm{C}_{7}-\mathrm{C} 8$ on the left; $\mathrm{C} 8-\mathrm{ThI}$ on the right; minimal compression of $\mathrm{C} 6$ with posterior luxation of the vertebral body. CT cuts obtained at $3 \mathrm{~mm}$ distance indicate minimal (A) and maximal (B) degree of cord compression.

Fractures of the atlas are often difficult to evaluate on plain film radiography. CT scans conveniently indicate the degree of luxation and spinal cord involvement. (Fielding et al., 1978; Kershner et al., I977).

In patients having had previous laminectomy we have seen progressive stenosis due to new bone formation which was not recognised on standard X-ray films.

\section{Degenerative lesions}

One of the main indications for spinal CT is degenerative spinal stenosis (Lee et al., 1978). The scan clearly reveals the degree of protrusion of osteophytes and calcified discs (Naidich et al., 1979). It also allows precise measurement of 

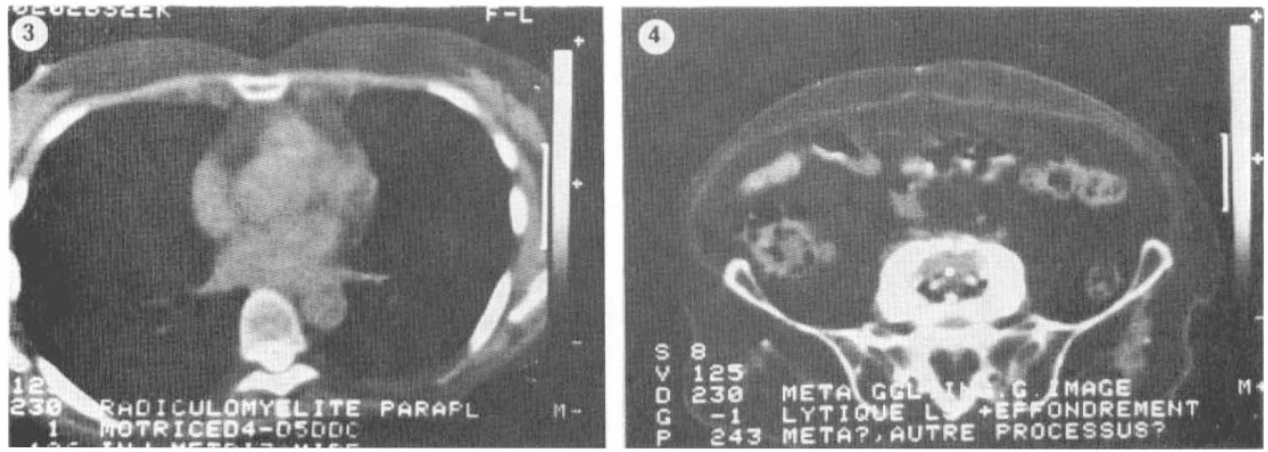

FIG. 3

Case 260202; female; age 54; complete paraplegia Th4-Th5; Myelomalacia of ischemic origin; iatrogenic consequence of aortic surgery; cord reduced to fibrous filament; opacification of subarachnoid space by $8 \mathrm{ml}$ of metrizamide.

FIG. 4

Case 3 I I I 4; male; age 49; complete traumatic paraplegia Th5-Th6 in I955; severe spondylarthrotic involvement of the lumbar spine since 5 years; partial compression of cauda equina at level $\mathrm{L}_{4}-\mathrm{L}_{5}$.

the narrowing of the lateral recess due to osteoarthritis of the facet joins. The configuration of this recess is determined by the interfacet distance and the height of the pedicles.

Since CT accurately reveals the shape and size of the cross-sectional area of the spinal canal it has become the procedure of choice to demonstrate lumbar spinal stenosis (Sheldon \& Sersland, 1977) and encroachment on the intervertebral foramina due to hypertrophy of the facet, a condition resulting in nerve root entrapment. Due to a phenomenon known as 'partial volume averaging' at the level of the articular segments there exists a certain risk of false positive findings (Fig. 4).

\section{Herniated discs}

As the resolution of the scanners improves, spinal CT is increasingly used in diagnosing herniated nucleus pulposus (Sheldon et al., 1976). In patients with intractable sciatic pain but no or only minimal neurological disorders, CT scans should be obtained as an early diagnostic procedure. In more complicated cases it is advisable to combine positive contrast myelography and CT. In order to yield optimal results in the study of herniated discs the scanner should have a spatial resolution of less than I $\mathrm{mm}$ and a lateral localiser allowing exact identification of the intervertebral space. Most authors suggest that the image should be analysed with window settings of $500 \mathrm{H}$.U. (Hounsfield Units) for soft tissue identification and 1000 H.U. for the study of the skeletal structures. In patients with low back pain and sciatica it may be expected that the proper use of CT scans will significantly lower the need for myelography.

\section{Syringomyelia}

With the aid of spinal CT Di Chiro and Axelbaum (1975) have been able to show cord cavitation in seven of nine cases with syringomyelia (Fig. 5). Zumpano (I978) observed hydromyelic cavities adjacent to an intramedullary metastatic medulloblastoma. In combination with metrizamide enhancement CT was shown 

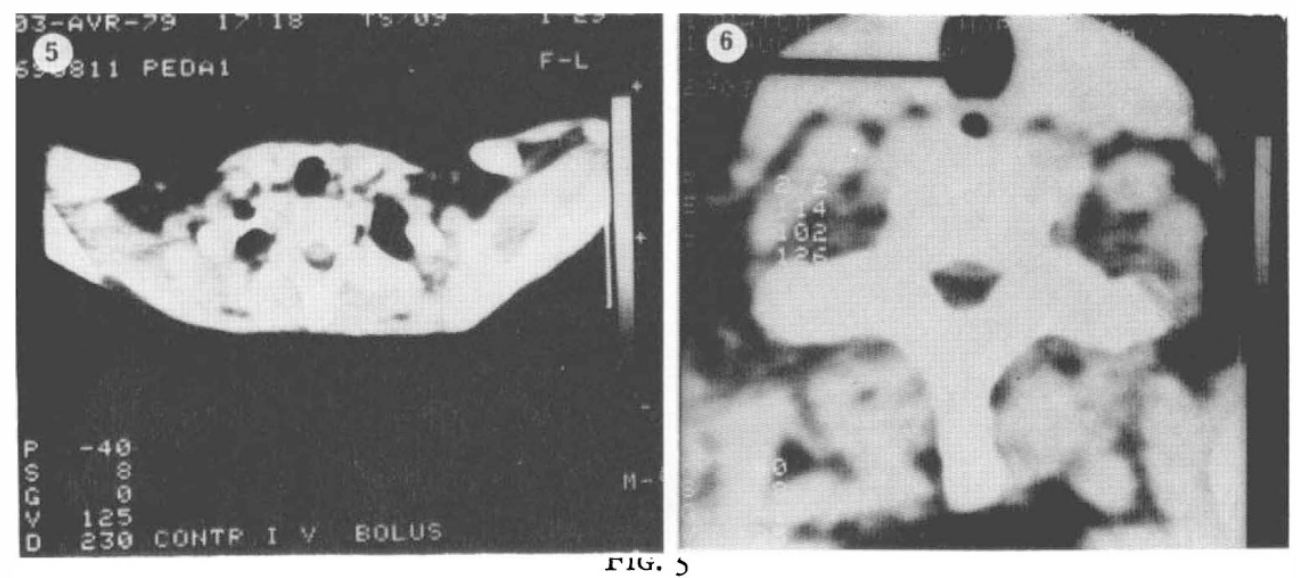

Case 6908II; male; age I2; incomplete tetraplegia C8-ThI; intramedullary polymorphous tumour extending from $\mathrm{C}_{4}$ down to $\mathrm{Th}_{5}$; partial neurosurgical excision in 1979 followed by radiotherapy; CT scan revealing degree of postactinic atrophic changes of the cord at level C6.

FIG. 6

Case 290320; female; age $5 \mathrm{I}$; incomplete tetraplegia C6-C 7 bilaterally with complete paraplegia below Th2; fracture of $\mathrm{C} 6$ with posterior dislocation over $\mathrm{C}_{7}$; progressive cystic degeneration of the cord, starting 8 months post-trauma, with neurological level rising to $\mathrm{C}_{4}$; CT scanning revealed intramedullary cyst extending from $\mathrm{C}_{4}$ to $\mathrm{Th}_{3}$.

to be very accurate in the differential diagnosis between spinal cord tumours and syringomyelia (Bonafe et al., I980; Handel et al., 1978). The exact identification of the level of the cavitation greatly facilitates the surgical approach and drainage (Forbes \& Isherwood, 1978). In communicating hydro-syringomyelia, Rinaldi et al. (1978) propose the intraventricular injection of metrizamide. After overflow of the contrast medium into the central canal of the cord, CT scanning reveals the exact shape and longitudinal extension of the syrinx. Most authors agree that ventricular puncture and metrizamide opacification remains the most efficient method in demonstrating communicating hydrosyringomyelia.

\section{Spinal dysraphism}

In children with diastematomyelia Pantopaque myelography fails to demonstrate the split cord in as much as 30 per cent to 40 per cent of the cases, whereas metrizamide-enhanced CT practically always clearly indicates the malformation. Resjö (1978) reports that in children with diastematomyelia CT is considerably more sensitive in demonstrating both the bony spurs and the splitting of the cord than conventional myelography. In patients with spinal dysraphism metrizamide CT, combined with plain roentgenograms, yields considerably more information than Pantopaque or gas myelography (Wackenheim, 1975). The diagnostic value of CT in children with congenital intra- and extramedullary masses such as dermoid cysts, neuroenteric cysts, teratomas, lipomas, etc. has already frequently been stressed (Lohkamp, Claussen \& Schuhmacher, I978). Resjö (I978) recently published a paper on a series of 25 children with spinal dysraphism. The amount of metrizamide required in this series of CT scans never exceeded $4 \mathrm{ml}$ of a solution of $170 \mathrm{mg} \mathrm{I} / \mathrm{I} 00 \mathrm{ml}$. The documents obtained were of excellent quality and allowed full appreciation of the underlying pathology. Although it is unlikely that 
CT scans will completely replace conventional myelography, the method will gain more and more interest since it provides an additional dimension which is of paramount importance in establishing the correct diagnosis.

\section{Tumours}

With metrizamide CT it is usually always possible to distinguish between extra- and intramedullary processes. The differentiation between intra- and extradural location is more difficult (Thijssen, I979).

\section{Multiple sclerosis}

Coin (1979) has shown that acute lesions of multiple sclerosis cause low density or isodense images that enhance following the intravenous injection of iodinated contrast material. In a case history concerning a 24-year-old male student vertebral angiography and complete myelogram were normal while CT showed enhancing lesions both in the brain and spinal cord.

\section{Conclusion}

The diagnostic value of spinal CT scanning depends essentially:

on the type of spinal or medullary pathology that requires assessment, the degree of spatial resolution provided by the CT equipment, the frequent association of intrathecal contrast media such as metrizamide.

In patients with upper cervical injuries CT scans consistently yield more complete information regarding the state of the cord than conventional radiography and tomography (Roub \& Drayer, 1979). At all levels the method is by far superior to gas and Pantopaque myelography in demonstrating the extent of cord compression and root involvement.

At the present time appropriate evaluation of the size, shape and density of intraspinal tumours is only possible with concomittant use of a contrast agent such as metrizamide. It may however be expected that the more refined CT technology will in the near future provide a degree of spatial resolution that makes the use of intrathecal contrast media obsolete.

Marked stenosis of the spinal canal can already be diagnosed on plain films and with conventional myelography. CT scans provide the ways and means of visualising bony encroachment of very little longitudinal extension. One should however consider that correct and reproducible data concerning the dimensions of the canal may only be obtained if meticulous positioning techniques are applied in all serial examinations. We may then conclude that spinal CT has added an important new dimension to the precise assessment of pathological conditions that affect the spatial relation between the cord and spinal canal. Computerised tomography does not replace myelography or standard tomography. It yields however valuable additional information that cannot be obtained otherwise.

\section{RÉSUMÉ}

La valeur diagnostique de la tomométrie axiale à l'ordinateur dépend essentiellement du type de pathologie vertébro-médullaire (traumatique, dégénérative, tumorale, etc.) qu'il s'agit d'explorer-du degré de résolution spatiale que l'on peut obtenir avec l'appareil CT 
qui est à disposition et enfin-de l'opacification quasi-systématique de l'espace sousarachnoïdien à l'aide de faible quantité d'un produit de contraste hydro-soluble, tel que le métrizamide.

Chez les patients atteints d'une lésion cervicale traumatique, la tomométrie axiale fournit des renseignements plus complets et plus précis concernant l'état de la moelle que toutes les méthodes radiologiques conventionnelles. Indépendamment du niveau fracturaire (cervical, dorsal ou lombaire), il nous semble que la méthode permet de mieux apprécier l'étendue de l'atteinte myéloradiculaire que la myélographie gazeuse ou celle à contraste positif.

A l'heure actuelle, l'évaluation précise de la taille et densité d'une tumeur intramédullaire exige encore la visualisation de l'espace sousarachnoïdien à l'aide d'un agent contraste (par exemple Amipaque). On peut cependant prévoir que l'introduction d'appareils de plus en plus perfectionnés permettra, dans un proche avenir, de travailler sans cet artifice.

Dans les ostéopathies dégénératives, la tomométrie axiale permet de localiser des rétrécissements segmentaires isolés et d'en apprécier l'étendue longitudinale. L'expérience des trois dernières années nous permet de conclure qu'en traumatologie vertébro-médullaire, la tomométrie axiale est un moyen de diagnostic complementaire extrêmement utile du fait de sa grande maniabilité, parfaite innocuité et relative rapidité, avantages que l'on ne saurait méconnaître chez nos patients polytraumatisés. Cette méthode nous fournit des renseignements qu'aucune autre technique n'est à même de produire.

\section{ZUSAMMENFASSUNG}

Die diagnostische Aussagekraft der Computertomographie bei vertebro-medullären Leiden hängst weitgehend von der jeweiligen primären Pathologie ab (traumatische, degenerative, tumorale Läsionen, usw.) Ausschlaggebend ist ausserdem die technische Leistungsfähigkeit des zur Verfügung stehenden Tomographen und Computers. Die Qualität der Schichtbilder kann mit Hilfe der intrathekalen Verabreichung geringer Mengen eines wasserlöslichen Kontrastmittels, z.B. Metrizamid, wesentlich verbessert werden.

Bei Patienten mit einem zervikalen Wirbeltrauma erblaubt die Computertomometrie eine genauere Abklärung der medullären und radikulären Beteiligung. Auf jeder Höhe-ob zervikal, thorakal oder lumbal, besitzt die Methode in der Regel eine bessere Aussagekraft als die Myelographie.

Die exakte Darstellung einer intramedullären Kyste oder eines Tumors ist zur Zeit nur möglich bei gleichzeitiger Verwendung eines Kontrastmittels (z.B. Amipaque). Mit den neueren, noch in der Entwicklung stehenden Prototypen wird dies jedoch nicht mehr nötig sein.

Bei degenerativen Osteopathien gestattet die axiale Tomometrie eine exakte Lokalisation der Wirbelkanalstenose und deren Ausmass.

Die seit 3 Jahren in unserem Zentrum regelmässig eingesetzte Computertomometrie hat sich bereits als eine sehr zuverlässige Untersuchungsmethode erwiesen, die den Standardroentgenbefund unterstützt und ergänzt.

\section{REFERENCES}

Aaro, S., Dahlborn, M. \& Svensson, L. (1978). Estimation of vertebral rotation in structural scoliosis by computer tomography. Acta Radiol. Diag., 6, 990-992.

Bonafe, A., Ethier, R., Melancon, D., Belanger, G. \& Peters, T. (I980). High resolution computed tomography in cervical syringomyelia. F. Comput. Assist. Tomogr., 4, $42-47$.

Coin, G., Keranen, V. J., Pennink, M. et al. (I978). Computerized tomography of the spine and its contents. Neuroradiology, 16, 27I-272.

Corn, C. G. \& HuCKs-Folliss, A. (I979). Cervical computed tomography in multiple sclerosis with spinal cord involvement. F. Comput. Assist. Tomogr., 3, 42I-422.

Colley, D. P. \& DUNSKer, S. B. (I978). Traumatic narrowing of the dorso-lumbar spinal canal demonstrated by computed tomography. Radiology, 129, 95-98.

Crolla, D., Hens, L., Wilms, G., Van Den Bergh, R. \& Baert, A. L. (I980). Metrizamide enhanced CT in hydrosyringomyelia. Neuroradiology, 19, 39-4I.

Di Chiro, G., Axelbaum, S. P., Schellinger, D., Twigg, H. L. \& Ledley, R. S. (1975). Computerized axial tomography in syringomyelia. N. Engl. F. Med., 292, I3-I6. 
Di Chiro, G. \& Schellinger, D. (I976). Computed tomography of the spinal cord after lumbar intrathecal introduction of metrizamide. Radiology, 120, IOI-IO4.

Di Chiro, G., Doppman, J. L. \& Wener, L. (I977). Computed tomography of Spinal cord arteriovenous malformation. Radiology, 123, 35I-354.

Fielding, J. W., Stillwell, W. T., Chynn, K. Y. \& SPyropoulos, E. C. (1978). Use of computed tomography for the diagnosis of atlanto-axial rotatory fixation. F. Bone foint Surg., 60-A, I IO2-I IO4.

ForBES, W. S. \& IsHERWOOD, I. (I978). Computed tomography in syringomyelia and the associated Arnold-Chiari type I malformation. Neuroradiology, 15, 73-78.

Hammerschlag, S. B., Wolpert, S. M. \& CARTer, B. L. (I976). Computed tomography of the spinal canal. Radiology, I 21, 36I-367.

Handel, S., Grossman, R. \& SaWAR, M. (I978). Computed tomography in the diagnosis of spinal cord astrocytoma. F. Comput. Assist. Tomogr., I, 377-390.

Haughton, V. M., Williams, A. L., Cusick, J. F. \& MeYer, G. A. (I978). A myelographic technique for cysts in the spinal canal and spinal cord. Radiology, 129, 717-719.

Jacobson, R. E., Gargano, F. P. \& Rosomoff, H. L. (I975). Transverse axial tomography of the spine. Neurosurg., 42, 406-4I9.

Kershner, M. S., Goodman, G. A. \& Perlmutter, G. S. (1977). Computed tomography in the diagnosis of an atlas fracture. Amer. F. Roentgenol., 128, 688-689.

Lee, B. C., Kazam, E. \& Newman, A. D. (1978). Computed tomography of the spine and spinal cord. Radiology, 128, 95-102.

LILIEQUIST, B. (I978). Computed tomography. Clinical aspects: cerebro-vascular diseases and head injuries. Acta Neurol. Scand., Suppl. 57, I65-175.

Lin, J. P., Pay, N., Naidich, T. P., KRIChefF, I. I. \& Wiggli, U. (I977). Computed tomography in the postoperative care of neurosurgical patients. Neuroradiology, 12, I 85-I89.

Lohkamp, F., Claussen, C. \& Schumacher, G. (1978). CT demonstration of pathologic changes of the spinal cord accompanying spina bifida and diastematomyelia. In Progress in Pediatric Radiology, Skull, Spine and Contents, Part II, Vol. 6, ed. H. J. Kaufmann, pp. 200-227. Basel, Karger.

Manelfe, C., Guiraud, B., Espagno, J. \& Rascol, A. (1978). Cisternographie computérisée au métrizamide. Rev. Neurol., 134, 47I-484.

Naidich, T. P., Moran, C. J., Pudlowski, R. M. \& Hanaway, J. (1979). Advances in diagnosis: cranial and spinal computed tomography. Med. Clin. North Amer., 63, $849-895$.

Oberson, R. \& AzAm, F. (1978). CAT of the spine and spinal cord. Neuroradiology, 16, 369-370.

Resjoe, I. M., Harwood-Nash, D. C., Fitz, C. R. \& Chuang, S. (i978). Computed tomographic metrizamide myelography in spinal dysraphism in infants and children. 7. Comput. Assist. Tomogr., 2, 549-558.

Rinaldi, I., Kopp, J. E., Harris, W. O., Reagan, T. J. \& Murphy, D. (I978). Computer assisted tomography in syringomyelia. F. Comput. Assist. Tomogr., 2, 633-635.

Roub, L. W. \& DRAYER, B. P. (I979). Spinal computed tomography: limitations and

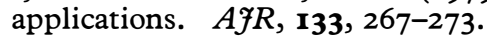

Scotti, L. N., Marasco, J. A., Pittman, T. A., Freczko, W. A. \& Goldman, R. L. (I977). Computed tomography of the spinal canal and cord. Comput. Tomogr., I, 229-234.

Sheldon, J. J., Russin, L. A. \& Gargano, F. P. (I976). Lumbar spinal stenosis. Radiographic diagnosis with special reference to transverse axial tomography. Clin. Orthop., II 5, 53-67.

Sheldon, J. J., Sersland, T. \& Leborgne, J. (I977). Computed tomography of the lower lumbar vertebral column. Normal anatomy and the stenotic canal. Radiology, 124, II3-II8.

SKalpe, I. O. \& Sortland, O. (1978). Cervical myelography with metrizamide. A comparison between conventional and computer-assisted myelography with special reference to the upper cervical and foramen magnum region. Neuroradiology, 16, 275-278.

Sortland, O., Lundervold, A. \& Nesbakken, R. (1977). Mental confusion and epileptic seizures following cervical myelography with metrizamide. A case report. Acta Radiol. (Stockh.), 355, 403-406.

Thijssen, H. O., KeYser, A., Horstink, M. W. \& Meijer, E. (1979). Morphology of the cervical spinal cord on computed myelography. Neuroradiology, 18, 57-62.

VAN DEN BERGH, R. (I975). Nieuwe inzichten in de pathogenese, de semeiologie en de behandeling van syringomyelie. Verh. vlaam. Akad. Geneesk. Belg., 37, 273-327. 
WACKENHEIM, A. (I975). Congenital fusion of the anterior arch of the atlas demonstrated by computed tomography. Radiology, II 7, 609-6I I.

Weinstein, M. A., Lederman, R. J., Rothner, A. D., Duchesneau, P. M. \& Norman, D. (1978). Interval computed tomography in multiple sclerosis. Radiology, 129, 689-694.

Westberg, G. (1966). Gas myelography and percutaneous puncture in the diagnosis of spinal cord cysts. Acta Radiol. (Suppl.), 252, I-67.

Zumpano, B. J. (1978). Spinal intramedullary metastatic medulloblastoma. F. Neurosurg., 48, 632-635. 